\title{
Exploring metal zoning in metapelitic porphyroblasts to reconstruct reaction histories and P-T-t-D paths \\ CHRIS MCFARLANE
}

University of New Brunswick

Presenting Author: crmm@unb.ca

In this contribution we examine the record of metamorphism as preserved by trace-element zoning across major-, minor-, and accessory minerals: some of these are both thermobarometers and petrochronometers (e.g., garnet by $\mathrm{Lu}-\mathrm{Hf} \& \mathrm{Sm}-\mathrm{Nd}$, micas by $\mathrm{Rb}-\mathrm{Sr}$ ). Of primary concern is the sequestration, liberation, intergranular diffusion, and partitioning behavior of slowdiffusing metals during progressive metamorphism of a clay-rich protolith (metapelite). These protoliths are typically endowed with a suite of elements that are enriched relative to the average continental crust: $\mathrm{Li}, \mathrm{Cs}, \mathrm{Ba}$, the transition metals $\mathrm{Co}-\mathrm{Ni}-\mathrm{Cu}-\mathrm{Zn}$, post-transition metals $\mathrm{Sn}-\mathrm{Tl}-\mathrm{Pb}$, metalloids $\mathrm{As}-\mathrm{Sb}-\mathrm{Te}$, and highfield strength elements Mo-W. Zoning in these elements helps fingerprint metamorphic reaction histories and supplements $\mathrm{Y}$ REE zoning in thermochronometers like garnet. Here we examine this problem by: 1) assessing trace-element content for all major, minor, and accessory phases in two metapelitic schists along the same prograde sequence; 2) calculating elemental budgets using micro-XRF phase mapping; 3) characterizing trace-metal zoning in aluminosilicates (garnet, biotite, chlorite, staurolite, chloritoid, plagioclase) and oxides (ilmenite); and 4) assessing potential reaction histories along a simple prograde $P-T$ path derived from thermodynamic modeling.

LA ICP-MS trace-element mapping and spot analyses reveals first-order metal fractionation: $\mathrm{Li}$ and $\mathrm{Zn}$ into staurolite; $\mathrm{P}, \mathrm{Pb}$, $\mathrm{Sr}$, LREE and $\mathrm{Ga}$ into plagioclase; $\mathrm{Li}, \mathrm{V}, \mathrm{Cr}, \mathrm{Co}, \mathrm{Ni}, \mathrm{Zn}, \mathrm{Rb}, \mathrm{Sn}$, $\mathrm{Cs}$, and $\mathrm{Tl}$ in micas; chlorite has the highest affinity for $\mathrm{Li}, \mathrm{Ni}$ and $\mathrm{Zn}$ among the sheet silicates; chloritoid also shows an affinity for $\mathrm{Zn}, \mathrm{Ge}$, and In. More importantly, well-preserved zoning for compatible trace elements can help reconstruct the metamorphic reaction history. In garnet a combination of $\mathrm{Y}, \mathrm{Li}$, $\mathrm{Eu} / \mathrm{Eu}^{*}, \mathrm{Sm}$, and HFSE can be used to reconstruct changing reaction history among Y-rich accessory minerals, chlorite, plagioclase, ilmenite and micas. Zoning $\mathrm{s}$ unmodified by diffusive re-equilibration and preserves evidence for discontinuous and continuous reactions. Biotite preserves zoning in $\mathrm{Cr}, \mathrm{Cs}, \mathrm{Nb}$ and $\mathrm{Sn}$ that could related to progressive consumption of chlorite, muscovite, and ilmenite.

When combined with spatially-resolved geochronology this approach adds extra dimensions to the record of metamorphic $P$ $T-t-D$ paths and takes advantage of porphyroblasts zoning patterns that are largely unexplored. 